\title{
The right to communicate employees of mass distribution in the sales area under Section 7
}

\section{Risa L. Lieberwitz}

\section{(2) OpenEdition \\ 1 Journals}

\section{Electronic version}

URL: https://journals.openedition.org/rdctss/906

DOI: $10.4000 /$ rdctss.906

ISSN: 2262-9815

\section{Publisher}

Centre de droit comparé du travail et de la sécurité sociale

\section{Printed version}

Date of publication: 1 December 2020

Number of pages: 172-175

ISSN: $2117-4350$

\section{Electronic reference}

Risa L. Lieberwitz, "The right to communicate employees of mass distribution in the sales area under Section 7", Revue de droit comparé du travail et de la sécurité sociale [Online], 4 | 2020, Online since 01 December 2020, connection on 26 January 2022. URL: http://journals.openedition.org/rdctss/906 ; DOI: https://doi.org/10.4000/rdctss.906

\section{(c) (i) (9)}

Revue de droit comparé du travail et de la sécurité sociale est mise à disposition selon les termes de la Licence Creative Commons Attribution - Pas d'Utilisation Commerciale - Pas de Modification 4.0 International. 


\section{RISA L. LIEBERWITZ}

CORNELL UNIVERSITY, SCHOOL OF INDUSTRIAL AND LABOR RELATIONS

\section{THE RIGHT TO COMMUNICATE EMPLOYEES OF MASS DISTRIBUTION IN THE SALES AREA UNDER SECTION 7}

The National Labor Relations Board (NLRB or Board) currently has only three of five seats filled. All three of the current Board members are conservative appointees nominated by President Trump and confirmed by a conservative U.S. Senate. The two vacant seats had been held by more liberal appointees who had been nominated by President Obama. The Trump administration has not yet presented nominations to the Senate to fill these two seats following the expiration of the Board members' terms.

The three-member Board majority has continued its pattern of narrowing employee rights under the National Labor Relations Act (NLRA) ${ }^{1}$, either by overruling or narrowing Board precedents. The Board has been particularly active in extending its line of decisions restricting the scope of employees' NLRA Section 7 rights to freely communicate about working conditions and unionization. One case concerned Walmart's workplace policy that granted employees the right to wear «small, non-distracting logos or graphics » such as buttons or pins no larger than their employee name badge ${ }^{2}$. Employees were wearing pins that included messages in support of " OUR Walmart » (Organization United for Respect at Walmart). The Board held that the Walmart policy was a lawful restriction on retail employees' Section 7 rights to communicate on the sales floor. However, the Board held that the policy violated Section 8(a)(1) of the NLRA when applied off the sales floor. Although this is a partial victory for the employees, the Board's analysis expands the scope of employer power to restrict employees' Section 7 rights at the workplace. The Board simply balanced employee business justifications for its policy against the impact of the policy on employees' Section 7 rights. This approach dilutes the traditional legal test that requires employers to prove "special circumstances " for restricting employees' Section 7 rights to communicate through wearing message pins or other insignia. In this case, Walmart should have been required to provide evidence of the business need to restrict the pins to the size of a small name tag. Instead, the Board simply accepted Walmart's assertion that wearing a larger pin on

129 U.S.C. $\S 151$ et seq.

2 Wal-Mart Stores, Inc., 368 NLRB no. 146 (2019). 
the sales floor would distract customers and would make it difficult to identify who was actually a Walmart employee ${ }^{3}$.

The Board applied this same deferential standard to employers in two other decisions upholding employer workplace confidentiality rules. In Apogee Retail $L L C^{4}$, the Board held that the employer did not violate Section 8(a)(1) by prohibiting employees from discussing workplace investigations, including investigations into illegal or unethical conduct. The Board held that investigative confidentiality rules are lawful as long as they clearly state that they apply only to the duration of the investigation. The Board concluded that such rules had only a slight impact on employees' Section 7 rights to discuss workplace issues, and that employer business justifications for confidentiality outweighed the employees' interests. However, the Board also held that it would evaluate, on a case-by-case basis, confidentiality rules that are not limited to open investigations. In such cases, the Board will balance employees' Section 7 rights against the employer's asserted business justifications to extend the length of the confidentiality requirement. Board member McFerran dissented from the three-member majority, arguing that the Board erred in overruling Board precedent that evaluated all workplace confidentiality rules on a case-by-case basis to determine whether the employer had sufficient business justifications ${ }^{5}$. McFerran was concerned with the chilling effect of such rules on employees' ability to discuss workplace issues under investigation, including employees under investigation who might seek co-workers' support. McFerran expressed similar concerns in her dissent from another Board decision finding that an employer does not violate Section $8(a)(1)$ by maintaining rules requiring employees to keep client/vendor lists confidential and prohibiting employees from providing information about company policies if the employees are approached by the media ${ }^{6}$. As McFerran explained, the Board majority ignored the employer's failure to narrowly tailor its rules in ways that would protect employees' Section 7 rights to share information about client identities with labor unions, to contact the employer's clients for support in labor disputes, or to contact the media about workplace issues.

The Board continued its recent line of decisions that place excessive weight on employer private property interests to the detriment of employees' Section 7 rights. In Caesars Entertainment d/b/a/ Rio All-Suites Hotel and Casino ${ }^{7}$, the threemember Board majority held that employers may prohibit employees from using employer-owned information-technology, including employer-owned email, for non-work-related communications. The majority overruled Purple Communications, Inc. ${ }^{8}$, which held that employees who are authorized to use the employer-owned email have Section 7 rights to use it for non-work purposes during non-working time. Employers could limit such use only if they could prove "special circumstances»

3 Board member McFerran, an Obama appointee, was still on the Board at the time Wal-Mart was decided. McFerran dissented from the majority's decision.

4368 NLRB no. 144 (2019).

5 See Banner Estrella Medical Center, 362 NLRB 1108 (2015).

6 LA Specialty Produce Company, 368 NLRB no. 93 (2019).

7368 NLRB no. 143 (2019).

8361 NLRB 1050 (2014). 
related to business needs. As Board member McFerran noted in her dissent in Caesars Entertainment, the majority's treatment of employer-owned email ignores the reality of the quotidien use of email and creates unjustified obstacles to employees' ability to exercise their Section 7 rights to communicate with each other about workplace issues.

In another recent decision, the Board made it more difficult for labor union representatives to enter the private property of the employer's business. Under long-standing Supreme Court precedent, employers may bar union representatives' access to the employer's private property, as long as the employer enforces its " no solicitation » rule in a non-discriminatory way ${ }^{9}$. In Kroger Mid-Atlantic ${ }^{10}$, the threemember Board majority held that the employer, a grocery store, lawfully barred labor union representatives from the store's parking lot, where they were collecting signatures from customers for a petition protesting employer labor practices. The Board upheld Kroger's enforcement of its no solicitation rule, even though Kroger had permitted charitable organizations, such as the Girl Scouts and the Salvation Army, to solicit donations and sell items in the parking lot. In reaching its conclusion, the Board overruled an earlier Board decision in Sandusky Mall Co. ${ }^{11}$, under which Kroger's action toward the union representatives would have been found discriminatory. In its decision in Kroger, the Board adopted a standard defining discrimination as unequal treatment by employers of activities that are " similar in nature ». Under this definition, the union representatives engaging in labor organizing or protests would not be engaged in activities similar to charitable, civic, or commercial activities of the other organizations permitted on Kroger's parking lot.

The NLRB issued several decisions building on the U.S. Supreme Court's precedents upholding the enforceability of mandatory agreements to arbitrate employment-related disputes in non-union workplaces ${ }^{12}$. Under such mandatory agreements, as a condition of employment, employees waive their rights to seek redress for legal claims through the courts. In 2018, in Epic Systems Corp. v. Lewis ${ }^{13}$, the Supreme Court held that employers do not violate the NLRA by imposing mandatory arbitration agreements that require employees to arbitrate their employment-related disputes individually, and to waive the right to resolve those disputes through collective actions. In one case after Epic Systems, the NLRB held that employers do not violate employees' Section 7 rights by imposing mandatory arbitration agreements requiring employees to arbitrate their employmentrelated disputes individually, even though the employer created these contractual provisions in response to employees' protected activity of joining a collective wage and hour claim ${ }^{14}$, The Board held, further, that employers do not violate the NLRA by threatening employees with discharge for failing to sign such mandatory arbitration

9 Lechmere, Inc. v. NLRB, 502 U.S. 527 (1992); NLRB v. Babcock \& Wilcox, Inc., 351 U.S. 105 (1956).

10 Kroger Limited Partners/hip I Mid-Atlantic, 368 NLRB no. 64 (2019).

11329 NLRB 618 (1999).

12 See AT\&T Mobility LLC v. Concepcion, 563 U.S. 333 (2011); Circuit City Stores, Inc. v. Adams, 532 U.S. 105 (2001).

13138 S.Ct. 1612 (2018).

14 Cordúa Restaurants, Inc., 368 NLRB no. 43 (2019). 


\section{UNITED STATES OF AMERICA}

agreements ${ }^{15}$, However, the Board has also held that mandatory arbitration agreements may not lawfully require employees to waive their rights to file claims with the NLRB or other administrative agencies ${ }^{16}$. Further, the Board has held that an employer violated employees' Section 7 rights by imposing a mandatory arbitration agreement that recognized employees' rights to file unfair labor practice charges with the NLRB, but prohibited the employees from receiving backpay or other monetary remedies for employer violations of the NLRA ${ }^{17}$.

15 Id. Board member McFerran dissented from both holdings in Cordúa Restaurants.

16 Prime Healthcare Paradise Valley, LLC, 368 NLRB no. 10 (2019).

17 Kelly Services, Inc., 368 NLRB no. 130 (2019). 